\title{
DEVELOPMENT AND TESTING OF A POST-INSTALLABLE DEEPWATER MONITORING SYSTEM USING FIBER-OPTIC SENSORS
}

\author{
Calvin H. Seaman \\ NASA-Johnson Space Center \\ Houston, TX, USA \\ Suy Q. Le \\ NASA-Johnson Space Center \\ Houston, TX, USA
}

\author{
David V. Brower \\ Astro Technology Inc. \\ Houston, TX, USA
}

\author{
Henry H. Tang \\ Aerodyne Industries, LLC \\ Houston, TX, USA
}

\begin{abstract}
This paper addresses the design and development of a fiberoptic monitoring system that can be deployed on existing deepwater risers and flowlines; and provides a summary of test article fabrication and the subsequent laboratory testing performed at the National Aeronautics and Space Administration-Johnson Space Center (NASA-JSC).
\end{abstract}

A major challenge of a post-installed instrumentation system is to ensure adequate coupling between the instruments and the riser or flowline of interest. This work investigates the sensor coupling for pipelines that are suspended in a water column (from topside platform to seabed) using a fiber-optic sensor clamp and subsea bonding adhesive. The study involved the design, fabrication, and test of several prototype clamps that contained fiber-optic sensors. A mold was produced by NASA using 3-D printing methods that allowed the casting of polyurethane clamp test articles to accommodate 4-inch and 8inch diameter pipes. The prototype clamps were installed with a subsea adhesive in a "wet" environment and then tested in the NASA Structures Test Laboratory (STL). The tension, compression, and bending test data showed that the prototype sensor clamps achieved good structural coupling, and could provide high quality strain measurement for active monitoring.

\section{INTRODUCTION}

This report documents a study carried out under a Space Act Agreement between NASA and Astro Technology Incorporated (ATI). NASA and ATI have entered into this agreement to collaborate on the development of technologies that can benefit both the U.S. Government Space Program and the oil and gas industry.

The specific task was to design and test a proof-of-concept fiber optic sensing device for in-situ installation on pipelines, risers, or other structures deployed in deep water. The function of the sensor device is to measure various signals such as stress, strain, and temperature in subsea pipeline structures. A general example of how the adhesive clamps may be applied to a Tension Leg Platform is shown in Figure 1.

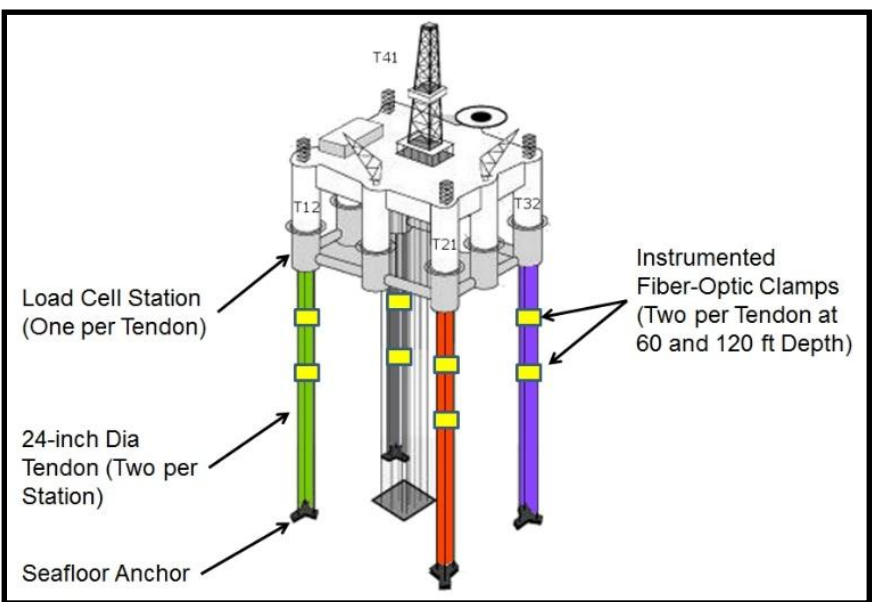

Figure 1. TENSION LEG PLATFORM EQUIPPED WITH FIBER-OPTIC SENSOR CLAMPS 


\section{DRAFT}

A fiber optic sensing system prototype, referred to as the "Adhesive Clamp," was jointly designed and built by NASA-JSC and ATI. The prototype device uses a marine bonding agent to enable in-situ underwater installation to pipeline structures. A diagram of some typical adhesive clamp configurations is shown in Figure 2.

In this study, adhesive clamp prototypes were built and tested to evaluate the feasibility of the attachment coupling and the corresponding quality of the sensor signal measurements. Three adhesive clamp prototypes were built and tested. The clamp prototypes were installed onto two different size steel pipes (4inch and 8-inch diameter) and tested in the STL. These tests evaluated the ability of the fiber optic sensors in the clamp prototypes to measure the strain generated by mechanically loading the test pipes in tension, compression, and bending modes. All the tests were conducted between July 18, 2013 and July 24, 2014.

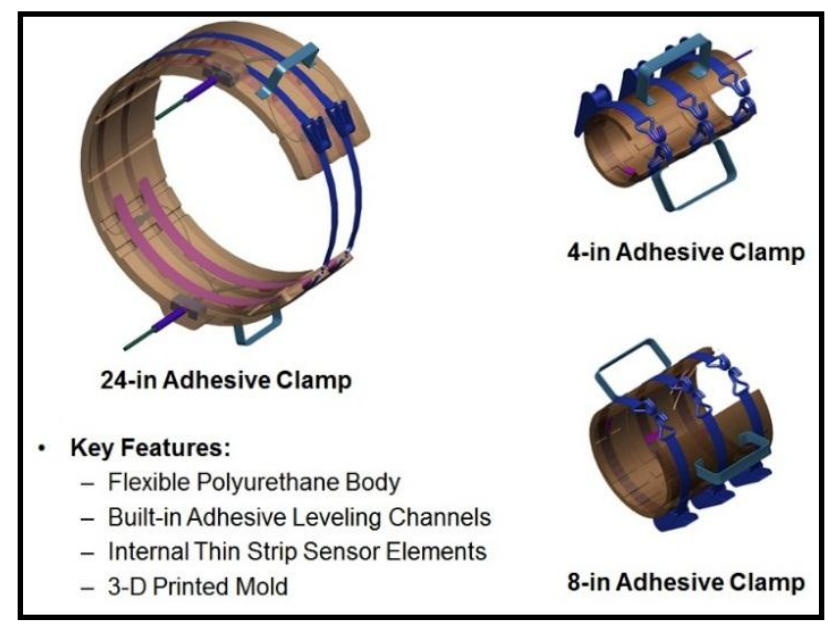

Figure 2. ADHESIVE CLAMPS

\section{ADHESIVE CLAMP DESIGN}

The adhesive clamp prototype was designed by NASA-JSC based on a concept proposed by ATI, and this configuration is fashioned primarily for diver installation in shallow water applications. The clamp uses a marine epoxy adhesive that is applied and allowed to cure underwater to permanently attach the fiber optic sensing system to the subsea structure. The clamp consists of a $\mathrm{C}$-shaped polyurethane body with externally mounted hand straps to aid the diver in flexing (opening) the clamp for installation. Fiber optic sensors are bonded to several metallic shims which are strategically placed and encapsulated within the casted polyurethane body at different locations and orientations to detect strain. The opposite side of the shims are exposed on the interior surface of the clamp, allowing rigid, contiguous, coupling with the structure that is being monitored.
Prior to installation, the clamp is thoroughly cleaned on a topside workbench, and then the interior surface is evenly coated with a generous layer of the subsea bonding adhesive. The adhesive has a 60 -minute pot life at $77 \mathrm{deg}$ F (25 C). Once the adhesive has been applied, the clamp assembly is promptly lowered to a commercial diver located at the underwater installation worksite. The clamp is oriented and attached by the diver, and manual ratchet straps are used to tightly secure the assembly to the structural interface. A network of grooved channels on the clamp interior surface allows the adhesive material to spread and migrate evenly to ensure a uniform layer between the clamp and the structure.

After a 24-hour cure period, the bonding is complete and the instrumentation system can be activated. Strains transferred from the structure to the metal shims are detected by the fiberoptic sensors. The signals are then routed through subsea cabling to a topside data acquisition system for collection and monitoring. Additional views of a typical adhesive clamp are shown in Figures 3 and 4.

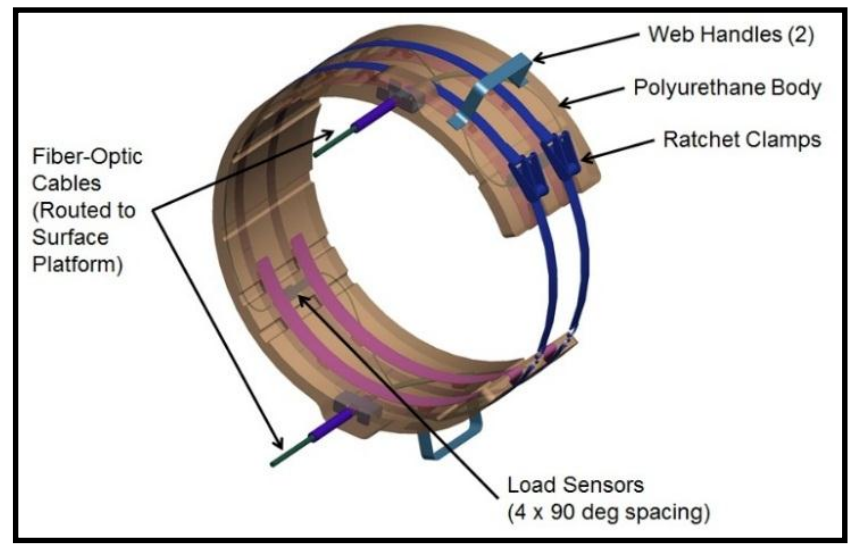

Figure 3. ADHESIVE CLAMP DESIGN

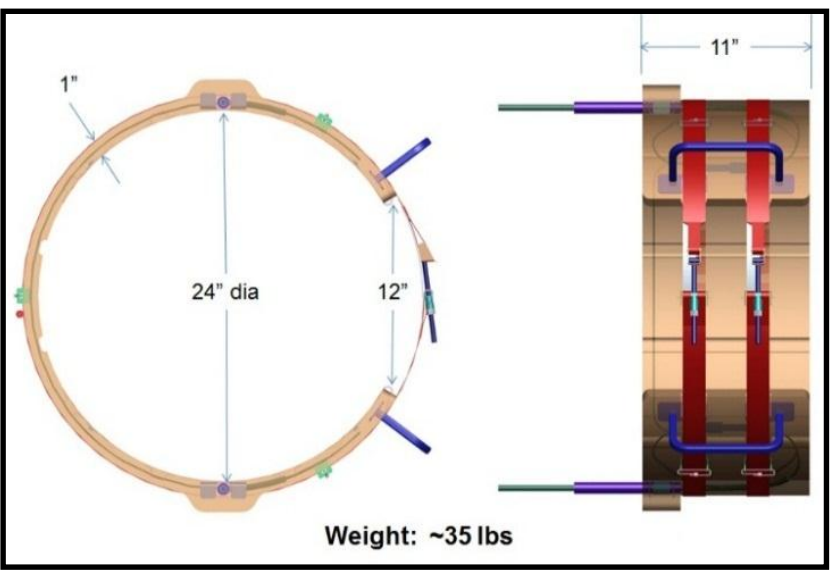

Figure 4. ADHESIVE CLAMP DESIGN 


\section{TEST METHODOLOGY}

A series of mechanical tests were conducted at NASA-JSC to evaluate the performance of the sensor clamp prototypes. These tests were designed to evaluate the strain measuring capabilities in an assembly configuration that is comparable to a realistic application in the oil \& gas industry. The relative accuracy and resolution of the strain measurements was used to infer the effectiveness of the prototype attachment mechanism and the reliability of the sensing system.

The prototype adhesive clamps were installed onto steel pipes, which simulate a pipeline structure, to form integrated test assemblies for mechanical loading and evaluation. The prototype clamps were installed onto the test pipes underwater to simulate a subsea application process. After installation, and a 48-hour underwater cure period, conventional resistance strain gauges were also installed on the pipes to complete the test assemblies. Each assembly was then subjected to various tension, compression, and bending loads, and the strain measurements from both the fiber optic sensors and the resistance strain gauges were recorded and evaluated. The measurements from the resistance strain gauges were used as a baseline reference to assess the accuracy and resolution of the prototype fiber optic sensor system. A detailed description of the test assemblies, test equipment, and test procedures are included in the following subsections.

\section{TEST ASSEMBLY}

A test assembly consists of a test pipe instrumented with a fiber optic sensor clamp prototype and a set of resistance strain gauges. Two different diameter steel pipes, 4-inch and 8-inch, were selected for use in this study. The pipes have a minimum yield strength of $65 \mathrm{ksi}$ and minimum tensile strength of $77 \mathrm{ksi}$. They are comparable to the API 5L PSL-2 X52 grade pipe. The 4" pipe is a NPS 4 Schedule 40 pipe with an outer diameter (OD) of 4.5 inches and wall thickness (WT) of 0.237 inch. The 8 " pipe is a NPS 8 Schedule 10 pipe with an OD of 8.625 inches and WT of 0.148 . The pipes used for the tension/ compression tests were 36 " long, 4" diameter and 8 " diameter. The pipe used for the bending tests was 120 " long and 8 " diameter. The 36 " long test pipes were weld fitted with a set of end-mounted pad eye fixtures to interface with the universal load cell machine for the tension/compression testing. These pipes were selected for a size and strength that would work effectively within the loading capabilities of the NASA static loading test fixture. A list of test assemblies is shown in Table 1 , and a schematic of a test assembly is shown in Figure 5.
Table 1. TEST ASSEMBLY LIST

\begin{tabular}{|c|c|c|c|c|}
\hline $\begin{array}{c}\text { Test Assembly } \\
\text { Number }\end{array}$ & Pipe Size & Pipe ID & Test Clamp & Test Type \\
\hline 1 & $\begin{array}{c}4.5 " \text { OD } \times 0.237 " \text { Wall } x \\
36 " \text { Length }\end{array}$ & P4-1 & None & $\begin{array}{c}\text { Tension \& } \\
\text { Compression }\end{array}$ \\
\hline 3 & $\begin{array}{c}4.5 " \text { OD x } 0.237 " \text { Wall } x \\
\text { 36" Length }\end{array}$ & P4-3 & Adhesive & $\begin{array}{c}\text { Tension \& } \\
\text { Compression }\end{array}$ \\
\hline 4 & $\begin{array}{c}3.625 " \text { OD x 0.148" Wall } \\
\text { x 36" Length }\end{array}$ & P8-1 & None & $\begin{array}{c}\text { Tension \& } \\
\text { Compression }\end{array}$ \\
\hline $5 b$ & $\begin{array}{c}\text { 3.625" OD x 0.148" Wall } \\
\text { x 36" Length }\end{array}$ & P8-2 & Adhesive & $\begin{array}{c}\text { Tension \& } \\
\text { Compression }\end{array}$ \\
\hline 7 & $\begin{array}{l}\text { 3.625" OD x 0.148" Wall } \\
\text { x 120" Length }\end{array}$ & P8-4 & None & $\begin{array}{c}\text { 4-Point } \\
\text { Bending }\end{array}$ \\
\hline 9 & $\begin{array}{c}\text { 3.625" OD x 0.148" Wall } \\
\text { x 120" Length }\end{array}$ & P8-6 & Adhesive & $\begin{array}{l}\text { 4-Point } \\
\text { Bending }\end{array}$ \\
\hline
\end{tabular}

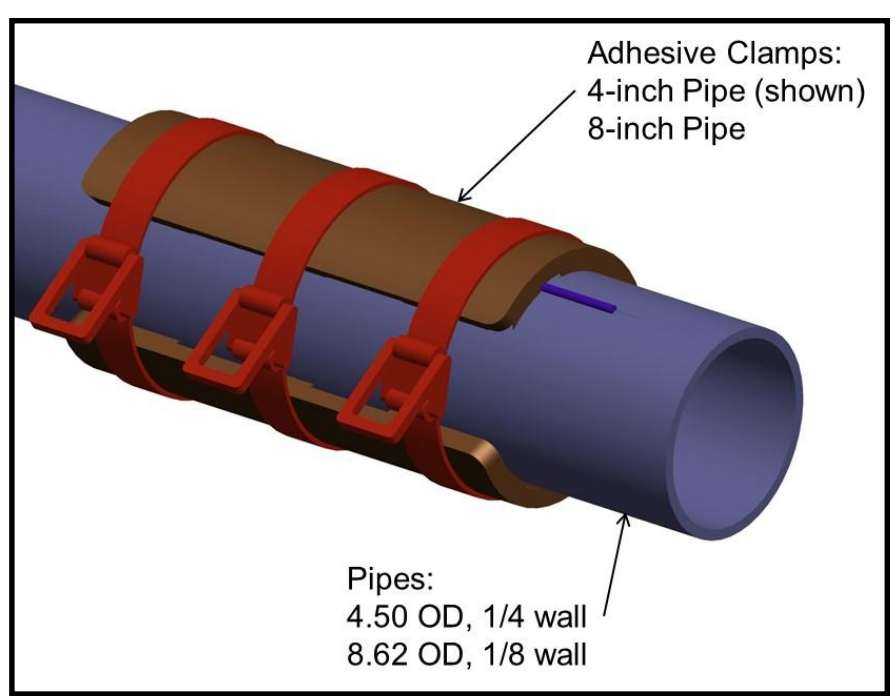

Figure 5. ADHESIVE CLAMP TEST ASSEMBLY

\section{TESTING AND EVALUATION OF BONDING ADHESIVE}

During the development of the adhesive clamp, a market survey was conducted to examine different commercial-off-theshelf adhesive systems designed for subsea application. Based on the findings from the survey, four subsea adhesives were selected for testing and evaluation. The adhesive with the best high-tensile bonding strength and good underwater handling characteristics was selected for the adhesive clamp application.

The tensile strength of the four epoxy-based adhesives were measured using the ASTM D2095 test method, Standard Test Method for Tensile Strength of Adhesives by Means of Bar and Rod Specimens. Adhesive test specimens prepared in both dry ambient air and synthetic seawater environments were tested in laboratory conditions. Table 2 summarizes the adhesive tensile test results. The Syntho-Subsea LV and WRA System 4302 have the highest wet-applied average adhesive tensile strength of 507 psi and 610 psi, respectively. Both adhesives manage to retain more than 62 percent of their dry average adhesive tensile strength when prepared underwater. The highest adhesive tensile strength data from these two adhesives indicate that up to 75 percent of the bonding strength could be maintained from optimal dry bonding versus bonding in a subsea environment. 


\section{DRAFT}

Table 2. ADHESIVE TENSILE TEST RESULTS

\begin{tabular}{|c|c|c|c|c|c|c|c|c|}
\hline \multirow{3}{*}{ Test Number } & \multicolumn{8}{|c|}{ Adhesive Tensile Strength (psi) } \\
\hline & \multicolumn{2}{|c|}{$\begin{array}{l}\text { West System Epoxy } 105 \text { and } \\
206 \text { Hardener }\end{array}$} & \multicolumn{2}{|c|}{ Syntho-Subsea LV } & \multicolumn{2}{|c|}{ WRA System 4302} & \multicolumn{2}{|c|}{ WRA System 4601} \\
\hline & Air & Seawater & Air & Seawater & Air & Seawater & Air & Seawater \\
\hline 1 & 481 & NAA & 709 & 595 & 1054 & 792 & 846 & 379 \\
\hline 2 & N/A & NA & 883 & 281 & 1000 & 435 & 807 & 475 \\
\hline 3 & 434 & NA & 881 & 556 & 947 & 673 & 835 & 549 \\
\hline 4 & 488 & NA & 617 & 417 & 970 & 84 & 953 & 410 \\
\hline 5 & 378 & NA & 897 & 687 & 940 & 539 & 753 & 560 \\
\hline Average & 445 & NA & 797 & 507 & 982 & 610 & 839 & 475 \\
\hline S.D. & 51 & NA & 127 & 159 & 46 & 156 & 73 & 81 \\
\hline
\end{tabular}

The Syntho-Subsea LV adhesive was found to be the easiest adhesive to handle and apply in underwater conditions according to subjective feedback from the technicians who prepared the test specimens. The Syntho-Subsea LV adhesive was selected for the adhesive clamp application for its high adhesive tensile strength and its ease of handling characteristics.

\section{ADHESIVE CLAMP PROTOTYPE TESTING}

Two different size sub-scale adhesive clamp prototypes were fabricated for testing: one 4-inch adhesive clamp and two 8 -inch adhesive clamps. The 4-inch adhesive clamp was used for tension/compression testing. One 8-inch adhesive clamp was also used for tension/compression tests and the other was used for 4-point bending tests. Figure 6 describes the fabrication process for a typical adhesive clamp.

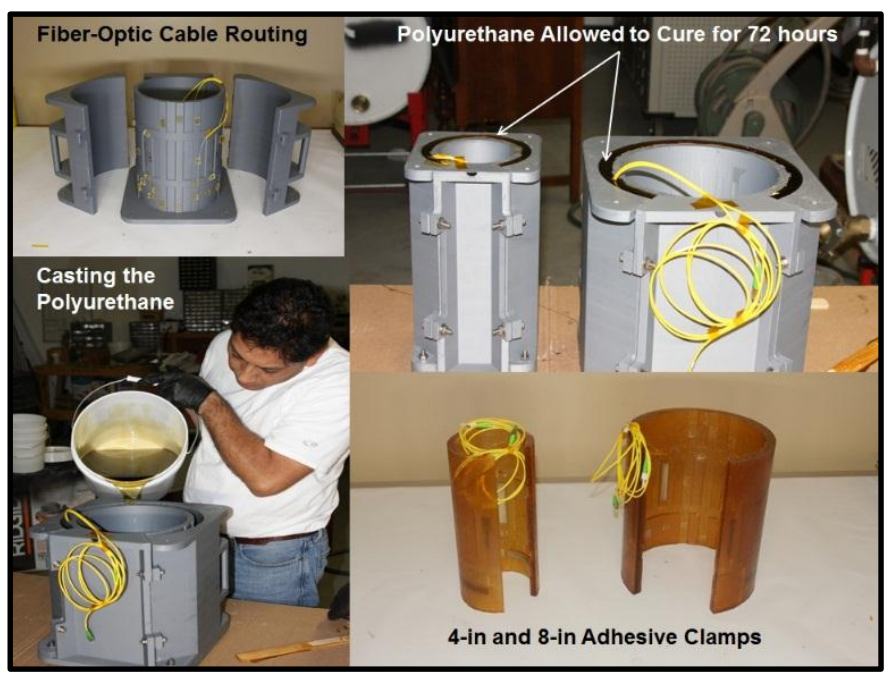

Figure 6. ADHESIVE CLAMP FABRICATION

All the adhesive clamp prototypes were fabricated by ATI. The molds that were used to cast the prototype polyurethane clamp body were manufactured by NASA using a 3-D printer. Each prototype has a set of six fiber optic sensors, each set consisting of 4 axial sensors and 2 transverse sensors. The axial sensors measure the tension and compression strains, and the transverse sensors measure the hoop strains. The four axial sensors are positioned 90 degrees apart along the circumference of the polyurethane shell. A typical layout of the sensors is shown in Figure 7.

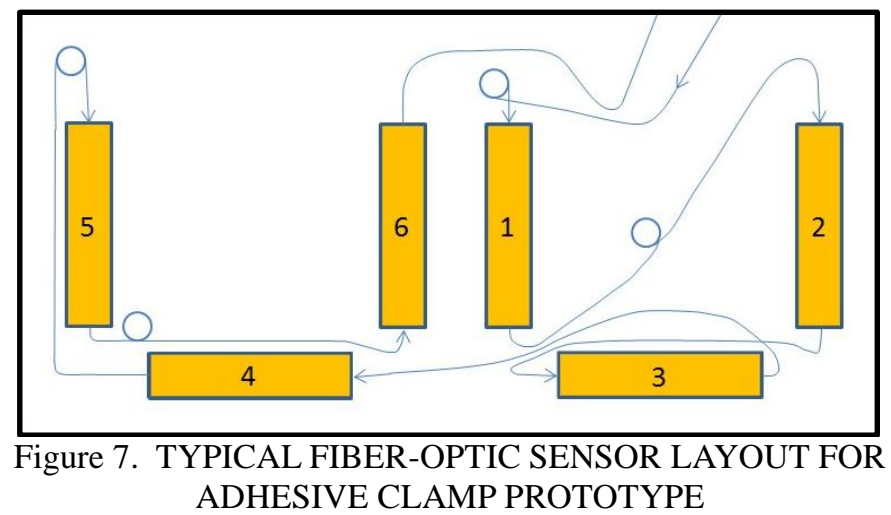

Each test assembly for tension/compression cycling was also instrumented with two axial resistance strain gauges bonded directly to the test pipe adjacent to the clamp. These strain gauges were positioned 180 degrees apart around the pipe circumference and the strain measurements from these strain gauges were used for comparison.

Two test assemblies were used for baseline testing to measure the force strain properties of the two different size test pipes. A hydraulic load frame was used to conduct all the tension/compression testing. A pair of hydraulic wedge grips was used to hold each pipe test assembly by gripping the integrated tab fixtures welded to each assembly end. The load frame and load cell have a 220,000 lbf maximum loading capacity. A $10 \mathrm{~Hz}$ data acquisition rate was used to record the resistance strain gauge data. Photographs of the tension/compression test setup are shown in Figure 8. The test assemblies were subjected to $\pm 110,000 \mathrm{lbf}$ with a corresponding strain of approximately $\pm 1250 \mu \mathrm{in} / \mu \mathrm{in}$. These tests were conducted at both low speed $(0.1 \mathrm{in} / \mathrm{min})$ and high speed $(0.5$ $\mathrm{in} / \mathrm{min}$ ) for up to 10 test cycles with 180 seconds hold time at each cycle peak and valley position. The tension/compression test matrix is shown in Table 3. 


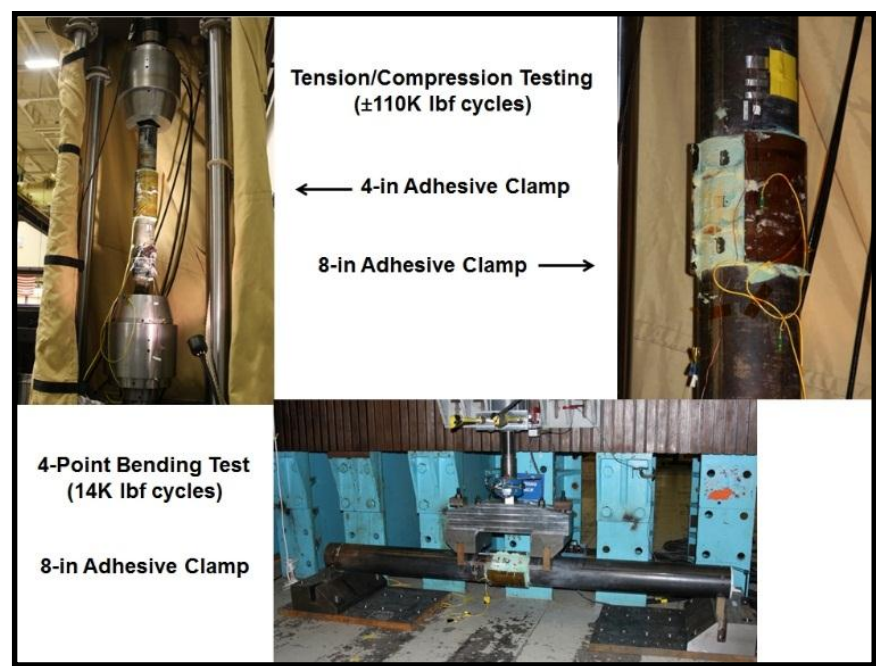

Figure 8. STATIC LOAD TESTING -

TENSION/COMPRESSION AND BENDING

Table 3. TENSION/COMPRESSION TEST MATRIX

\begin{tabular}{|c|c|c|c|c|c|c|}
\hline $\begin{array}{c}\text { Test } \\
\text { Number }\end{array}$ & $\begin{array}{l}\text { Test Ref. } \\
\text { ID }\end{array}$ & Test Articles & $\begin{array}{c}\text { Test } \\
\text { Configuration }\end{array}$ & $\begin{array}{l}\text { Test } \\
\text { Speed }\end{array}$ & $\begin{array}{l}\text { Hold Time } \\
\text { (seconds) }\end{array}$ & $\begin{array}{c}\text { No. of } \\
\text { Repeat } / \\
\text { Cycle }\end{array}$ \\
\hline TC-1-1 & Pretest1 & \multirow{4}{*}{$\begin{array}{l}4.5^{\prime \prime} \mathrm{OD} \times 0.237^{\prime \prime} \text { Wall } \\
\times 36^{\prime \prime} \text { Length Pipes } \\
\text { (Test Assembly \# 1) }\end{array}$} & \multirow{8}{*}{$\begin{array}{l}\text { Baseline (No } \\
\text { Clamp) }\end{array}$} & $\mathrm{N} / \mathrm{A}$ & $\mathrm{N} / \mathrm{A}$ & 1 \\
\hline TC-1-2 & Test1 & & & Low & 180 & 10 \\
\hline TC-1-3 & Test2 & & & High & 180 & 10 \\
\hline TC-1-4 & Test5 & & & N/A & $N / A$ & $\mathrm{~N} / \mathrm{A}$ \\
\hline TC-1-5 & Pretest2 & \multirow{4}{*}{$\begin{array}{c}\text { 8.625" OD x 0.148" } \\
\text { Wall x } 36 " \text { Length } \\
\text { Pipe (Test Assembly \# } \\
4)\end{array}$} & & N/A & N/A & 1 \\
\hline TC-1-6 & Test3 & & & Low & 180 & 10 \\
\hline TC-1-7 & Test4 & & & High & 180 & 10 \\
\hline TC-1-11 & Test6 & & & N/A & $\mathrm{N} / \mathrm{A}$ & N/A \\
\hline TC-3-1 & $\begin{array}{c}\text { 4in } \\
\text { Pretest1 }\end{array}$ & \multirow{3}{*}{$\begin{array}{l}4.5^{\prime \prime} \text { OD x } 0.237^{\prime \prime} \text { Wall } \\
\times 36 " \text { Length Pipes } \\
\text { (Test Assembly \# 3) }\end{array}$} & \multirow{6}{*}{ Adhesive Clamp } & $\mathrm{N} / \mathrm{A}$ & N/A & 1 \\
\hline TC-3-2 & Test1 & & & Low & 180 & 10 \\
\hline TC-3-3 & Test2 & & & High & 180 & 10 \\
\hline TC-3-4 & $\begin{array}{c}\text { 8in } \\
\text { Pretest1 }\end{array}$ & \multirow{3}{*}{$\begin{array}{c}\text { 8.625" OD x 0.148" } \\
\text { Wall x 36" Length } \\
\text { Pipe (Test Assembly \# } \\
5 b)\end{array}$} & & N/A & N/A & 1 \\
\hline TC-3-5 & Test3 & & & Low & 180 & 10 \\
\hline TC-3-6 & Test4 & & & High & 180 & 10 \\
\hline TC-4-1 & Test5 & $\begin{array}{c}4.5^{\prime \prime} \text { OD x 0.237" Wall } \\
\text { x 36" Length Pipes } \\
\text { (Test Assembly \# 3) }\end{array}$ & \multirow[b]{2}{*}{ Adhesive Clamp } & Low & 180 & 10 \\
\hline TC-4-2 & Test6 & $\begin{array}{c}8.625 " \text { OD x 0.148" } \\
\text { Wall x 36" Length } \\
\text { Pipe (Test Assembly \# } \\
10)\end{array}$ & & Low & 180 & 10 \\
\hline
\end{tabular}

The 4-point bending tests were performed after the completion of the tension/compression tests. The baseline 4point bending test served as the reference, where resistance strain gauge measurements were used to compare to the fiber optic sensor strain measurements to assess the clamp prototype performance. Since it was impossible to co-locate the resistance strain gauges on the pipe surface with the clamp prototype bonded in place, testing and comparing measurements from a baseline test, with the same sensor layout, was a practical approach for the study.

The 4-point bending tests were also performed at the NASAJSC STL. A strongback wall fixture with a hydraulic actuator was used to conduct the testing. A set of custom-built 4-point bending support fixtures was used to align and load the test assemblies. A $10 \mathrm{~Hz}$ data acquisition rate was used for all of the testing. A magnetic strip with rotational degree markings was attached to the end of each pipe to identify the rotational positioning of the test assembly. A photograph of the 4-point bending test setup is shown in Figure 8.

The 4-point bending tests were conducted in both low and high loading rates of $0.1 \mathrm{in} / \mathrm{min}$ and $0.5 \mathrm{in} / \mathrm{min}$. For each loading cycle, the test assembly was subjected to approximately 14,500 lbf bending force that generated up to $\pm 1400 \mu \mathrm{in} / \mu \mathrm{in}$ strain at the middle of the test assembly. At the peak of each loading cycle, the test fixture would hold at the corresponding position for a set time period of 30 seconds. Tests were conducted at different rotational positions ranging from zero to 315 degrees to vary the strain levels experienced by the different fiber-optic sensors and strain gauges. The detailed test parameters of all the bending tests are shown in Table 4.

Table 4. BENDING TEST MATRIX

\begin{tabular}{|c|c|c|c|c|c|c|c|}
\hline $\begin{array}{l}\text { Test } \\
\text { Number }\end{array}$ & $\begin{array}{l}\text { Test Ref. } \\
\text { ID }\end{array}$ & Test Articles & $\begin{array}{c}\text { Test } \\
\text { Configuration }\end{array}$ & \begin{tabular}{|c|} 
Rotational \\
Position \\
(Degree) \\
\end{tabular} & $\begin{array}{l}\text { Test } \\
\text { Speed }\end{array}$ & $\begin{array}{l}\text { Hold Time } \\
\text { (seconds) }\end{array}$ & $\begin{array}{l}\text { No. of } \\
\text { Cycle }\end{array}$ \\
\hline B-1-1 & Pretest1 & \multirow{11}{*}{$\begin{array}{l}\text { 8.625" OD x } \\
0.148 " \text { Wall x 120" } \\
\text { Length Pipe (Test } \\
\text { Article \# 7) }\end{array}$} & \multirow{11}{*}{$\begin{array}{l}\text { Baseline (No } \\
\text { Clamp) }\end{array}$} & 0 & $\mathrm{~N} / \mathrm{A}$ & $N / A$ & 1 \\
\hline B-1-2 & Test1 & & & 0 & High & 180 & 10 \\
\hline B-1-3 & Test2 & & & 0 & High & 30 & 1 \\
\hline B-1-4 & Test3 & & & 0 & High & 30 & 1 \\
\hline B-1-5 & Test4 & & & 30 & High & 30 & 10 \\
\hline B-1-6 & Test5 & & & 45 & High & 30 & 10 \\
\hline B-1-7 & Test6 & & & 90 & High & 30 & 10 \\
\hline B-1-8 & Test7 & & & 180 & High & 30 & 10 \\
\hline B-1-9 & Test8 & & & 270 & High & 30 & 10 \\
\hline B-1-10 & Test9 & & & 0 & Low & 30 & 5 \\
\hline B-1-11 & Test10 & & & 90 & Low & 30 & 5 \\
\hline B-3-1 & Pretest1 & \multirow{14}{*}{$\begin{array}{l}\text { 8.625" OD x } \\
0.148^{\prime \prime} \text { Wall x 120" } \\
\text { Length Pipe (Test } \\
\text { Article \# 9) }\end{array}$} & \multirow{14}{*}{$\begin{array}{l}\text { Adhesive } \\
\text { Clamp }\end{array}$} & 0 & High & 30 & 1 \\
\hline B-3-2 & Test1 & & & 0 & High & 30 & 10 \\
\hline B-3-3 & Test2 & & & 0 & High & 120 & 3 \\
\hline B-3-4 & Test3 & & & 30 & High & 30 & 10 \\
\hline B-3-5 & Test4 & & & 45 & High & 30 & 10 \\
\hline B-3-6 & Test5 & & & 90 & High & 30 & 10 \\
\hline B-3-7 & Test6 & & & 180 & High & 30 & 10 \\
\hline B-3-8 & Test7 & & & 270 & High & 30 & 10 \\
\hline B-3-9 & Test8 & & & 135 & High & 30 & 10 \\
\hline B-3-10 & Test9 & & & 225 & High & 30 & 10 \\
\hline B-3-11 & Test10 & & & 315 & High & 30 & 10 \\
\hline B-3-12 & Test11 & & & 0 & Low & 30 & 5 \\
\hline B-3-14A & Test13A & & & 90 & High & 30 & 5 \\
\hline B-3-14A & Test13B & & & 90 & High & 30 & 5 \\
\hline
\end{tabular}

\section{ADHESIVE CLAMP PROTOTYPE TEST RESULTS}

The strain measuring capability of the adhesive clamp prototype was evaluated by comparing the fiber optic sensor strain measurements from the prototypes to the corresponding instrumented strain gauge measurements. The ratio or percentage of the sensor measurement to strain gauge measurement was calculated to assess the strain sensing resolution of the sensor. A sensor with $100 \%$ resolution will provide the same strain measurement reading as a resistance strain gauge attached directly to the test pipe surface. The adhesive clamp sensing resolution data from all the tension/compression tests are presented in Table 5. The maximum tensile sensing resolution and maximum compressive strain resolution were calculated using the peak strain value from 


\section{DRAFT}

the most sensitive axial fiber optic sensor in the test. The minimum tensile strain resolution and minimum compressive strain resolution were calculated using the peak strain value from the least sensitive axial fiber optic sensor in the test. The adhesive clamp sensing resolution data from all the 4-point bending tests are presented in Table 6 . The red colored values in the table were calculated with the baseline test strain gauge data. The other data were calculated using values from strain gauges located adjacent to the clamp.

Table 5. ADHESIVE CLAMP FIBER OPTIC SENSOR RESOLUTION - TENSION/COMPRESSION TESTS

\begin{tabular}{|c|c|c|c|c|c|c|c|}
\hline $\begin{array}{c}\text { Test } \\
\text { Number }\end{array}$ & $\begin{array}{c}\text { Assembly } \\
\text { Type / } \\
\text { Number }\end{array}$ & $\begin{array}{l}\text { Number } \\
\text { of Test } \\
\text { Cycles }\end{array}$ & $\begin{array}{l}\text { Number of } \\
\text { Accumulative } \\
\text { Test Cycles }\end{array}$ & $\begin{array}{l}\text { Maximum } \\
\text { Tensile Strain } \\
\text { Sensing } \\
\text { Resolution } \\
(\%)\end{array}$ & $\begin{array}{c}\text { Maximum } \\
\text { Compressive } \\
\text { Strain } \\
\text { Sensing } \\
\text { Resolution } \\
(\%) \\
\end{array}$ & $\begin{array}{l}\text { Minimum } \\
\text { Tensile Strain } \\
\text { Sensing } \\
\text { Resolution } \\
(\%)\end{array}$ & $\begin{array}{c}\text { Minimun } \\
\text { Compress } \\
\text { Strain } \\
\text { Sensing } \\
\text { Resolutic } \\
(\%) \\
\end{array}$ \\
\hline TC-3-1 & \multirow{4}{*}{$\begin{array}{c}4 " \\
\text { Adhesive } \\
\text { Clamp / } \\
\# 3\end{array}$} & 1 & 1 & N/A & $N / A$ & N/A & $N / A$ \\
\hline TC-3-2 & & 10 & 11 & 89.9 & 91.8 & 19.2 & 27.0 \\
\hline TC-3-3 & & 10 & 21 & 86.5 & 86.7 & 19.3 & 22.6 \\
\hline TC-4-1 & & 10 & 31 & 87.8 & 85.8 & 18.2 & 19.6 \\
\hline TC-3-4 & \multirow{4}{*}{$\begin{array}{c}8^{\prime \prime} \\
\text { Adhesive } \\
\text { Clamp / } \\
\# 5 b\end{array}$} & 1 & 1 & N/A & $\mathrm{N} / \mathrm{A}$ & $\mathrm{N} / \mathrm{A}$ & $\mathrm{N} / \mathrm{A}$ \\
\hline TC-3-5 & & 10 & 11 & 96.1 & 95.2 & 26.4 & 35.8 \\
\hline TC-3-6 & & 10 & 21 & 97.3 & 99.3 & 26.2 & 33.7 \\
\hline TC-4-2 & & 10 & 31 & 98.8 & 98.2 & 24.9 & 34.0 \\
\hline
\end{tabular}

Table 6. ADHESIVE CLAMP FIBER OPTIC SENSOR RESOLUTION - 4-POINT BENDING TESTS

\begin{tabular}{c|c|c|c|c|c|}
\hline Test Number & $\begin{array}{c}\text { Rotational } \\
\text { Position } \\
\text { (Degree) }\end{array}$ & $\begin{array}{c}\text { Number of } \\
\text { Test } \\
\text { Cycles }\end{array}$ & $\begin{array}{c}\text { Number of } \\
\text { Accumulative } \\
\text { Test Cycles }\end{array}$ & $\begin{array}{c}\text { Maximum Tensile } \\
\text { Strain Sensing } \\
\text { Resolution (\%) }\end{array}$ & $\begin{array}{c}\text { Maximum } \\
\text { Compressive } \\
\text { Strain Sensing } \\
\text { Resolution (\%) }\end{array}$ \\
\hline B-3-1 & 0 & 1 & 1 & N/A & N/A \\
\hline B-3-2 & 0 & 10 & 11 & 22.6 & 69.5 \\
\hline B-3-3 & 0 & 3 & 14 & 21.6 & 63.2 \\
\hline B-3-4 & 30 & 10 & 24 & 19.0 & 57.8 \\
\hline B-3-5 & 45 & 10 & 34 & 17.8 & 56.8 \\
\hline B-3-6 & 90 & 10 & 44 & 85.9 & 82.2 \\
\hline B-3-7 & 180 & 10 & 54 & 25.2 & 19.8 \\
\hline B-3-8 & 270 & 10 & 64 & 83.2 & 17.4 \\
\hline B-3-9 & 135 & 10 & 74 & 20.2 & 17.8 \\
\hline B-3-10 & 225 & 10 & 84 & 21.8 & 19.7 \\
\hline B-3-11 & 315 & 10 & 94 & 17.2 & 21.5 \\
\hline B-3-14A & 90 & 5 & 104 & 25.7 & 56.6 \\
\hline B-3-14B & 90 & 5 & 109 & 24.8 & 42.3 \\
\hline
\end{tabular}

At least one of the axial sensors from both the 4-inch and 8inch adhesive clamp prototypes exhibited very high sensing resolution in the tension/compression tests. The highest performing sensor in the 8-inch adhesive clamp had a 95\% sensing resolution throughout the tension/compression test series. Both adhesive clamps can measure tensile strain and compressive strain equally well with high resolution. The least sensitive sensors were only maintaining $18 \%$ or higher sensing resolution. It appears that the least sensitive sensors may have lost direct coupling with the test pipe surface but still provided indirect sensing of the strain through the polyurethane clamp body, which maintained coupling with the test pipe. The adhesive clamp prototype did not work as well in the 4-point bending tests. A couple of the axial sensors managed to provide high resolution data up to $86 \%$ at the beginning of the testing. However, as the number of test cycles increased, the sensors became less responsive and were more susceptible to data dropouts. It is suspected that the relatively large flexural displacement created by the bending force may have decoupled or damaged some of the sensors during testing. The test assembly was deflected 0.5 inch at the full stroke of the bending tests.

The following is a summary of what was learned about the adhesive clamp prototype from this study:

- The adhesive clamp prototype has a robust sensor coupling interface that produced high resolution strain measurements.

- The underwater installation and curing of the adhesive clamp is a viable method for attaching fiber optic sensors to a pipe structure, and is capable of providing quality strain sensing data.

- Sensor coupling could be degraded by large displacement bending cycles. As the number of bending cycles increased, some of the sensor resolution decreased correspondingly.

- When a sensor lost direct coupling with the pipe surface, it was still capable of providing indirect strain measurement through the coupling between the polyurethane clamp body and the pipe surface.

\section{RECOMMENDED FUTURE IMPROVEMENTS FOR ADHESIVE CLAMP DEVELOPMENT}

The findings from this study demonstrated that the adhesive attachment method is a viable concept for fiber optic strain sensing applications. However, more work is needed to refine the current adhesive sensor clamp designs to create a more robust sensing system. The following is a list of proposed future improvements to the adhesive clamp to provide more accurate, reliable, and durable sensing data.

- Improve the adhesive clamp fiber optic sensor anchoring and attachment methods, such as using different size and shape metal shims to enhance bonding and coupling of the sensors.

- Incorporate additional sensors to provide redundancy in case of sensor failure to improve overall system reliability.

- Investigate the feasibility of utilizing the indirect strain sensing through the polyurethane clamp body. This will provide a secondary measuring capability in the event of direct sensor decoupling.

- Investigate the feasibility of formulating mathematical transfer functions to interpolate the low resolution indirect strain measurement data for accurate strain sensing. 


\section{DRAFT}

ACKNOWLEDGMENTS TBD.

\section{REFERENCES}

TBD. 


\section{DRAFT}

ANNEX A

PUT ANNEX TITLE HERE

Put text of Annex here 